\title{
Production and Marketing System of Kampong Chicken in Batang Regency, Central Java, Indonesia
}

\author{
Agus Setiadi*, Siswanto Imam Santoso, Suryani Nurfadillah, Kadhung Prayoga and Enggar Prasetyo \\ Department of Agribusiness, Faculty of Animal and Agricultural Science, \\ Universitas Diponegoro, Semarang, Indonesia \\ *Corresponding author: agus_setiadi2006@yahoo.co.id
}

\begin{abstract}
Kampong chicken is an indigenous chicken that gains popularity among consumers and it has good potentials as a livestock commodity. But, the problem is most kampong chicken were kept in free range system without any standard of the rearing procedure and time. The farmers will sell their chickens by market's requests. The study aims to determine the agribusiness production and marketing sub-system of kampong chickens. A hundred kampong chicken farmers from 9 sub-districts in Batang Regency were interviewed. Respondents were chosen by simple random sampling. Each farmer owned 4-120 kampong chickens with average number of 6.76 heads per farm. The poultry production sub-system consisted of six constituent variables, namely administration/bookkeeping, location, maintenance technology, maintenance system, business continuity and sanitation. Each constituent variable produced score of $1.44 ; 1.75 ; 1.68 ; 2.77 ; 1.55$ and 2.03 respectively with the average value of 1.87 . These results indicated that the applications of agribusiness production sub-systems were in the moderate category. The assessment of the marketing sub-system application included five variables namely marketing scale, marketing objectives, marketing technology, market information and pricing with the following scores $1.52,1.76,1.41,1.85$ and 1.18 respectively; or have an average value of 1.54 . This result showed that the marketing sub-system has a moderate category. Improving the production system which consisted of the bookkeeping record, increase the number of rearing scale and sanitation process would improve farm productivity. Increasing marketing systems such as the application of electronic marketing would improve market efficiency. The results showed that the improvement of production and marketing agribusiness sub-systems are needed in order to increase farmers' income.
\end{abstract}

Keywords: agribusiness; kampong chicken; marketing; production; village

Cite this as: Setiadi, A., Santoso, S. I., Nurfadillah, S., Prayoga, K., \& Prasetyo, E. (2020). Production and Marketing System of Kampong Chicken in Batang Regency, Central Java, Indonesia. Caraka Tani: Journal of Sustainable Agriculture, 35(2), 326-336. doi: http://dx.doi.org/10.20961/carakatani.v35i2.40907

\section{INTRODUCTION}

The poultry sector is one of the prospective sectors to develop in Indonesia. Chicken has become a commodity that has a large market, including kampong chicken. The reasons are the healthy living culture that is popular in the community. There is a view in society that kampong chicken has a higher nutritional content than broiler chickens. Kampong chickens are reported to have high protein and low cholesterol caused the demand for kampong chicken meat is very high (Setiadi et al., 2016). This condition also explained by Rasyaf (2010) and Anas et al. (2020) that the demand for kampong chicken meat will be in line with community needs, so it will be potential. Data from BPS-Statistics Indonesia (2019) noted down that the level of consumption

\footnotetext{
* Received for publication March 29, 2020

Accepted after corrections September 1, 2020
} 
of chicken meat per capita increased from $5.5 \mathrm{~kg}$ in 2018 to $6.2 \mathrm{~kg}$ in 2019 . This data certainly illustrates the fact that raising chicken is one of the prospective choices to make.

Many kampong chickens are reared in rural areas for meat and egg production purposes. In some countries, indigenous chicken plays an important role to support food security (Abdelqader et al., 2007; Halima et al., 2007; Muchadeyi et al., 2007; Sow and Grongnet, 2010; Rodríguez et al., 2011; Okeno et al., 2012; Mahoro et al., 2017; Moussa et al., 2019). Unfortunately, kampong chicken farming is mostly done by small holder farmers with traditional farming system. Most kampong chickens were reared with free-range system where the animals can roam freely in search for food. Setiadi et al. (2016) stated that village chickens are reared in rural areas by $80 \%$ of the Indonesian population. Sofyan et al. (2019) also said that chicken rearing in rural areas contributes to support food security.

One of the reasons why kampong chicken in Indonesia is still being reared on a small business scale because it is only used as an additional income by the community. Nowadays, more people consider farming in the fields as the main source of income. Meanwhile, when there is an unplanned expenditure or a special event then the kampong chickens are being sold or utilized. The eggs produced are used by the families for side dishes and protein additions. Free-range chicken is still not seen as a viable commodity. Free-range chickens are still seen as savings that can be sold at any time when they need money. This conditions was also found in Batang Regency, Central Java Province. Batang Regency is one of the centers of kampong chicken business in Central Java; with the farmers are still adopting traditional production system. Kampong chicken farmers in Batang Regency reared the kampong chicken in free range. Such a production system will certainly hamper the development of the kampong chicken business. This is the reason behind this paper; to learn about the existing kampong chicken production system and how it should be done.

Aside from the production system, the marketing system of the kampong chicken also has many problems. At the current market, the price of kampong chicken and/or its meat is very unstable. There are times when the price is very expensive when certain days such as religious holidays. However, often the price is in a low position because people prefer broiler chicken meat. However, despite several problems such as sub optimal management practices and fluctuating meat prices; the main problem faced by kampong chicken farmers is the expensive feed price. This happens because most of the feed ingredients are imported from other countries such as corn and soybean meal. Within the scope of local chicken development, Widjastuti et al. (2018) explained the main problems of local chicken farming are the low availability of day old chicks, low productivity and the traditional production system. One way to overcome the problems above is by implementing a good practice in agribusiness system.

The study aimed to analyze the production performance and marketing sub-system of kampong chickens in the Batang Regency, Central Java, Indonesia. The purpose raised from this study is different from other studies that make kampong chicken as the object of research. Research conducted by Oskar et al. (2013) and Sinaga et al. (2014) only looked at the factors influencing consumer behavior in consuming kampong chicken meat. Meanwhile, Hasriani et al. (2019) analyzed the factors that influenced the demand for kampong chickens. Others, Rosningsih (2012) see more changes in the socioeconomic conditions of kampong chicken farmers after the existence of a mini integrated farming program. There is also Suharyon et al. (2020) who look more at the economic and institutional aspects of kampong chicken farming. Loing and Makalew (2016); Penggu et al. (2014); and Widyantari (2015) also specialize in their research on the financial feasibility and farming of kampong chicken. Finally, a study from Homer et al. (2017) emphasized the problems and scenarios of developing kampong chicken farms. From these various studies, it can be seen that this paper shall provide an understanding and different views on the production and marketing system of kampong chickens which were not available in the previous researches. Also, the farmers are still focused on the production, haven't really involved in marketing practice.

\section{MATERIALS AND METHOD}

Research on the analysis of kampong chicken business was carried out in the Batang Regency area, Central Java, Indonesia. Batang Regency 
was chosen because of the high growth of its kampong chicken production. Specifically, there are nine sub-districts which are used as research samples, namely Bawang, Tersono, Limpung, Gringsing, Subah, Batang, Reban, Blado and
Bandar. These nine sub-districts were chosen because they were the centers of kampong chicken production in Batang Regency. The sample distribution of respondents is shown in Table 1.

Table 1. Sample distribution every sub-district

\begin{tabular}{|c|c|c|c|}
\hline No. & Sub-district name & Number of respondents (person) & Percentage (\%) \\
\hline 1. & Bawang & 52 & 52 \\
\hline 2. & Tersono & 18 & 18 \\
\hline 3. & Limpung & 8 & 8 \\
\hline 4. & Gringsing & 7 & 7 \\
\hline 5. & Subah & 5 & 5 \\
\hline 6. & Batang & 4 & 4 \\
\hline 7. & Reban & 2 & 2 \\
\hline 8. & Blado & 2 & 2 \\
\hline 9. & Bandar & 2 & 2 \\
\hline
\end{tabular}

In this study, observations and structured interviews were carried out with the help of questionnaires for all 100 respondents. From these interviews, the primary data obtained regarding the characteristics of respondents, production and marketing systems. Additional data such as the use of inputs, income and production costs were also collected. Positive questions weighting was as followed: good $=3$, medium $=2$, low $=1$. Meanwhile, secondary data which assumed to affect the study including population of kampong chickens in the study location, marketing institutions, selling prices of kampong chicken and the number of kampong chicken farmers. Secondary data was obtained from the institutions related to the research such as livestock service offices from village level to sub-district level, under the Ministry of Agriculture and the Central Statistics Bureau (BPS) and sources of references.

The analysis for the implementation of agribusiness sub-system activities on kampong chicken business was carried out by the method of calculating the average value of a variable in the agribusiness sub-system namely production and marketing system with 3 (three) scales based on the existing ratio. The distribution of scales in each sub-system of agribusiness is based on fairness and mutually exclusive considerations. The three scales were:

1. < 1.00 (insufficient / implementing a low agribusiness sub-system);

2. $1.01-2.00$ (moderate / sufficient to apply the agribusiness sub-system) and;

3. > 2.01 (good / apply almost every sub-system of agribusiness).

There were 6 variables for production sub-system assessment i.e. administration/ bookkeeping, location, maintenance technology, system maintenance, business continuity and sanitation. And there were 5 variables for marketing sub-system assessment i.e. marketing scale, marketing objectives, marketing technology, market information and pricing determination. Profitability analysis also used to measure the level of profitability in kampong chicken business, For income $(\mathrm{Y})$ are measured based on the amount of the IDR unit obtained after deducting operational costs per month and analyzed quantitatively by the formula from Soekartawi (2006):

$$
\begin{aligned}
Y & =T R-T C \\
Y & =Q \times P q \\
T C & =T V C \times T F C
\end{aligned}
$$

Information:

$\mathrm{Y} \quad=$ Revenue $\left(\right.$ IDR month $\left.^{-1}\right)$

$\mathrm{TR}=$ Total revenue (IDR month ${ }^{-1}$ )

$\mathrm{TC}=$ Total cost (IDR month $\left.{ }^{-1}\right)$

$\mathrm{Q} \quad=$ Kampong chicken products $(\mathrm{kg})$

$\mathrm{Pq}=$ Product price $\left(\right.$ IDR head $\left.{ }^{-1}\right)$

TVC $=$ Total variable costs $\left(\right.$ IDR month $\left.^{-1}\right)$

TFC $=$ Total fixed costs (IDR month $\left.{ }^{-1}\right)$ 


\section{RESULTS AND DISCUSSION}

The majority of respondents are males, although some are females. The women become kampong chicken farmers because of their small business scale. Their main task is from feeding to staging; considering the traditional system of freerange in raising kampong chicken. The average age of respondents is still considered as the young category. As a result, the respondent's experience in raising kampong chickens is still short. As presented in Table 2, the majority of respondents were graduated from senior high school. Basically, there is no significant difference between elementary school and senior high school graduates in rearing kampong chickens. Given the similarity in the way the chicken farming is carried out. The problems which were faced together are the ones related to knowledge about feed and disease management.

Table 2. Characteristics of respondents

\begin{tabular}{lcr}
\hline Respondent data & Number (person) & Percentage (\%) \\
\hline Gender & & \\
Male & 92 & 92 \\
Female & 8 & 8 \\
Age (year) & 6 & 6 \\
$\leq 20$ & 28 & 28 \\
$\geq 21-30$ & 41 & 41 \\
$>31-40$ & 23 & 23 \\
$>41-50$ & 2 & 2 \\
$>51$ & & \\
Educational background & 21 & 21 \\
Elementary school & 27 & 27 \\
Junior high school & 42 & 42 \\
Senior high school & 10 & 10 \\
Diploma/bachelor & & \\
Length of experience (year) & 62 & 62 \\
1 & 25 & 25 \\
2-3 & 9 & 9 \\
4 & 4 & 4 \\
$>$ 5 & &
\end{tabular}

This result was supported by Moussa et al. (2019) which stated that more educated farmers will be faster to adopt innovations compared to farmers with lower education. This result also in agreement with Okeno et al. (2012) which stated educational background support the business successibility of the farmer. Increasing formal and informal education would increase the ability to handle chicken and to apply the management practice of the chicken rearing business. Thus, the farmers who completed minimum education at the secondary level are most likely to adopt new technology and experience the yield augmenting effects of education (Paltasingh and Goyari, 2018).

The length of experience in kampong chicken business would influence the success of the business. Research from Rahmah (2015) and Widyantari (2015) also indicates that chicken farmers who have more than 5 years of farming experience have relatively a lot of experience. This experience then becomes a source of knowledge and skills for farmers. Studies from Teklewold et al. (2006) and Setiana et al. (2019) even explain that the length of farming affects the farmers' skills in choosing local chickens to rear. Mastuti and Hidayat (2009), Rahayu et al. (2014), also Ja'far et al. (2019) even recommend farmers to increase their experience in order to facilitate the technology adoption process so that they will increase their income continuously.

The majority experience of raising kampong chicken was 1-2 years. Lack of experience caused the farmers' rearing/production process and market understanding were not good enough. Following the statement of Mtileni et al. (2013) that the experience of a farmer would certainly facilitate a farmer in carrying out his chicken 
business and would be able to determine whether kampong chicken farmers were able to achieve their goals. Rodríguez et al. (2011) in the results of their study mentioned that length of experience in handling indigenous chicken would increase the chicken rearing business success. Finally, $91 \%$ of respondents also said that Kampong chicken business was a side business. The low experience in raising kampong chicken makes the development tends to be slow; hence, additional knowledge in rearing kampong chicken is still needed.

\section{Production system}

The livestock production system which was examined at the kampong chicken farms in Batang Regency consisted of six constituent variables. The average value was 1.87 , in general these results indicated that the implementation of the agribusiness production system was still in the moderate criteria. The following is a display of the bar diagram in Figure 1.

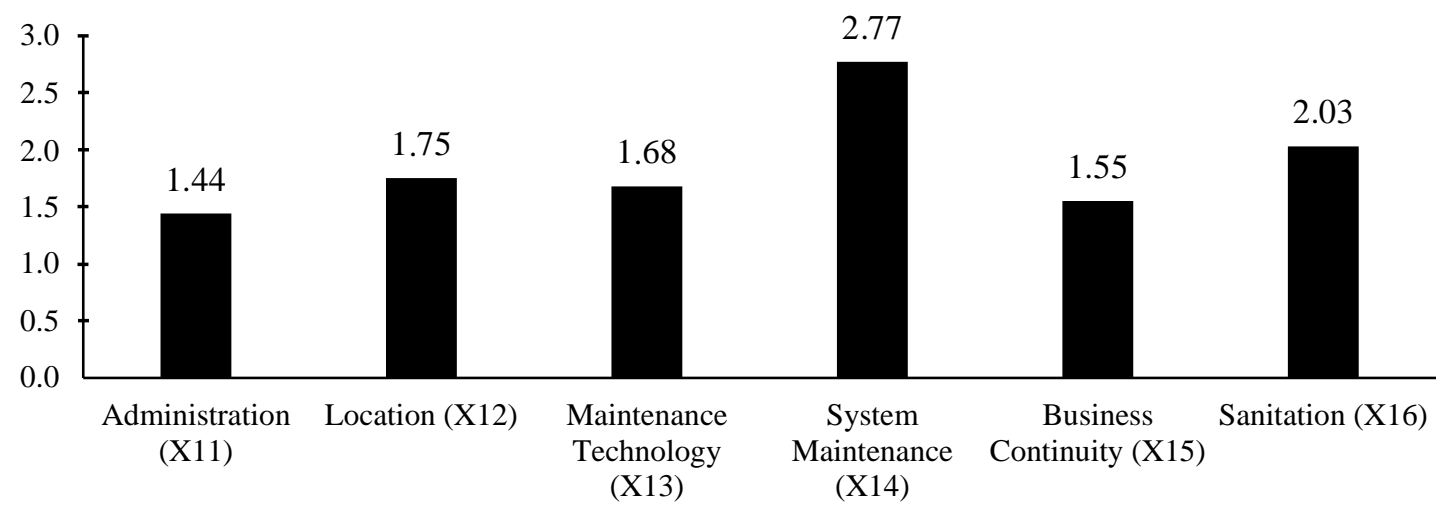

Figure 1. Score diagram of production system

The survey results stated that $80 \%$ of respondents in this study were considered as moderate in administration and bookkeeping. This can be seen from the relevant score (1.44). Bookkeeping and administration are still limited to recording buying and selling transactions and have yet to record the activities of the daily tasks in chicken rearing. Also, the existence of recording could be used to estimate the amount of expenditure during the rearing period so that the price of production could be calculated. In bookkeeping matters, more extra cautions must be made according to the type of costs incurred to produce the company's products (Abdelqader et al., 2007).

The recording practice of kampong chicken business rearing in this study was categorized as moderate. Farmers did not always record daily activities regularly. This condition occurs because according to the farmers, the kampung chicken rearing was done only as side businesses. Moreover, the number of chickens owned is also considerably small. Farmers also think that recording will cost time and energy because it is not the main source of income. Of course, this is not in line with the findings of Setiadi et al. (2016) that recording included production, health management and the total number of sick and healthy chicken should be recorded everyday. According to Gondwe and Wollny (2007) without good administrative recording, the chicken business would not develop. In accordance with this research, farmers should improve the administrative records.

Technology in kampong chicken business production was moderate (1.68). The score was marked as the lowest frequency of feeding which is ideally regular 3 times a day, practically the feed was given 2 times a day. The chickens were fed once in the morning and after that the farmers let them go to roam. The drinking water, however, was provided add libitum. Day Old Chicks (DOC) were handled well. Sugar water as an anti-stress was given to the DOC. This was consistent with the research from Sofyan et al. (2019) that the first thing we must do after the DOC came is the provision of drinking water mixed with $1-2 \%$ sugar water and anti-stress medication. Sugar water mixing is intended to replace body fluids and energy lost during the transportation from the breeding farms.

Another technology is the vaccination program. Vaccination programs which was 
carried out by farmers was the New Cattle Disease (ND) vaccinations. Meanwhile, farmers with less than 5 chickens do not vaccinate. Information about vaccinations was only obtained from other farmers. The vaccinations given were ND B1 (age 4 days), gumboro vaccine (age 14 days) and ND Lasota (age 21). The vaccines were given either by injection or through drinking water. The Avian influenza (AI) vaccination, however, has not been regularly given. By the statement of Muchadeyi et al. (2007) and Mtileni et al. (2013) that the method of vaccination that can be carried out by farmer includes: 1) eye/nose drops carried out on young chickens (1-4 days), 2) through drinking water carried out on aged chickens 4 weeks or more, 3 ) by spray, carried out on adult chickens, 4) intra muscular injection in adult chickens.

The rearing system at the kampong chicken business in Batang Regency has been well implemented. This can be seen from the score that shows 2.77 , this is reasonable considering that of the three existing chicken rearing systems namely traditional chicken farming systems, semi-intensive farming systems, intensive farming systems, kampong chicken farmers in the $76 \%$ of Batang Regency have developed intensive chicken farming systems. Intensive rearing is a combination of activities related to the use of technology, management and land use that provides optimal efficiency. The intensive farming system of kampong chicken is similar as the rearing of broilers.

The chicken were kept within a special cage or a fenced yard and not freely roaming and foraging (Sekeroglu and Aksimsek, 2009). Intensive kampong chicken rearing business in Batang Regency can be interpreted as an effort to improve the way of rearing from traditional to support productivity. In the intensive farming system, chicken were kept in cages and supported sufficient feed both in quality and quantity as well as good rearing management. The ultimate goal is to get the maximum profit possible, a study from Wantasen et al. (2014) and Setiana et al. (2019) also found the same thing, namely that chicken which were reared in semi-intensive system produces more profit rather than traditionally reared. Outside Indonesia, research from Mahoro et al. (2017) explains that the extensive scaling management system that is widely used in developing countries is not efficient in terms of production and finance. Added by Haunshi et al. (2009) that indigenous chicken production could perform better for economic purposes if reared with good management.

Sanitation activities carried out at kampong chicken business was considerably good. This can be seen from the score which reached 2.03. Even so, the sanitation activities carried out at kampong chicken business in Batang Regency are still simple and not comprehensive such as cleaning the cage regularly once a week and before DOC comes during the rearing period, cleaning feed and drinking water once a week, cleaning the environment inside the cage with indeterminate time intervals and outside the cage and litter replacement, the litter is added if the litter already looks wet and is no longer comfortable to be inhabited by chickens because a wet litter would facilitate ND.

The sanitation activities were actually barely optimal. Good sanitation activities are comprehensive sanitation, including sanitation of cages, keeping the cage litter dry and does not cause odor, cleaning feed and drinking areas and also cleaning chicken manure (Desta and Wakeyo, 2012). Good sanitation can inhibit the presence of germs at any time (Desta and Wakeyo, 2013).

\section{Marketing system}

The assessment of the application of the marketing sub-system of kampong chicken farms in Batang Regency which includes five variables namely marketing scale, marketing objectives, marketing technology, market information. As shown in Figure 2 marketing sub-system has moderate criteria. Based on Figure 2 the highest value was market information, while the lowest was in the ability to determine prices. The scale of marketing carried out at kampong chicken farms in Batang Regency was moderate. This can be seen from the score which reached was 1.52 because after experiencing the harvest period, kampong chicken can be directly sold to the centers of traditional markets which are not far from the production center. Another thing that makes the low price determination score was the weak bargaining position of farmers, especially farmers with small ownership. Usually, farmer setting the selling price. In line with Sow and Grongnet (2010), they found that the selling price determination mechanism is by following the prevailing market price, while the selling price formed later is the result of negotiations between the company and the buyer. 


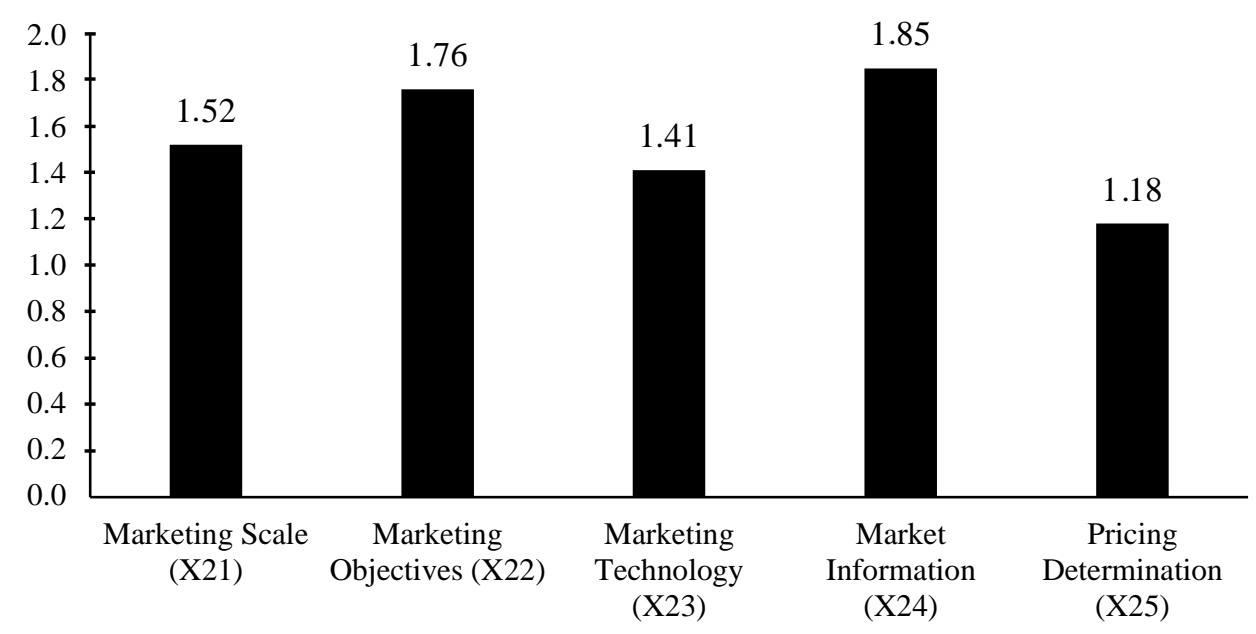

Figure 2. Score diagram marketing system

The method of calculating the selling price is based on the formula of adding the cost of raw materials, service costs, processing costs and profits. Wholesalers always comes to buy both in regencies and outside regencies such as Pekalongan Regency, Kendal Regency and Temanggung Regency. From this situation, the marketing scale still potent to be expanded to other areas outside Batang Regency, province and even to the national scale. The larger scale of marketing will create more the opportunities for development. Comparable to the scale of marketing, the marketing objectives carried out at the kampong chicken business in Batang Regency was moderate. This can be seen from the score which reached 1.76. Kampong chicken marketing, both DOC, ready-to-cut chickens, or eggs was sold to wholesalers or directly to the market. Farmers raised 6.76 heads of kampong chicken on average.

Market information is the variable with the highest value in the marketing sub-system but it is still in the moderate criteria (1.85). This is due to the average farmers knowing the price development once a week from the wholesaler. Market information is also closely related to the use of communication technology as a means. The use of cell phones, the internet and social media as a means of communication is widely used by kampong chicken farmers in Batang. Marketing should be improved through the application of electronic marketing. This is in accordance with the opinion of Sofyan et al. (2019) whom stated that the utilization of the latest technology, consistency in maintaining quality, product durability and the use of a lightweight and convenient packaging materials according to international standards would improve their image and customer satisfaction.

The function of providing marketing information in the era of globalization is very important in helping decision makers by marketing actors because it is always supported by existing data and facts (Gondwe and Wollny, 2007). Pricing determination at kampong chicken farms in Batang Regency has a score of 1.18 or the lowest of all marketing variables. The lowest score indicates that farmers are the price takers based on market mechanisms. Usually, wholesalers will be able to set the price. It can be seen that this low value is because the farmers directly sell it to wholesalers and only accept prices from wholesalers. Farmers are afraid if the chickens do not sell, they will incur large additional costs; hence, they will be sold at prices from the wholesalers. Meanwhile, farmers with a small number of chickens have a tendency to not be too involved in the bargaining process because only a few are sold. The principle that they profess is the most important practice.

Based on Table 3 and Table 4, the calculation and business analysis, the value of the BEP unit in kampong chicken farmers in Batang was 61 heads of kampong chicken and the BEP price is IDR 23,360. This result is supported by Henning et al. (2006) which stated that increasing cost efficiency would increase the profit. The income obtained per bird was IDR 16,000. Although from the calculation results this business will paid off when the chickens owned 
are 61 heads. However, on average, each farmer has 6 heads and remains profitable for several reasons, mainly because many costs are not taken into account. For example, labor is not counted because it is provided by the wife at home. Feed also comes from household food waste, so it costs nothing. Chickens are even accustomed to looking for their own food because they are free to roam. There is also no cage, even though it is very simple only from bamboo so that the farmers only spend a little effort. Chickens that are raised without significant effort from the farmers will eventually grow up and sold, so it seems profitable.

Table 3. Income of kampong chicken farmer per head of kampong chicken raised

\begin{tabular}{clc}
\hline No. & \multicolumn{1}{c}{ Items } & Number (IDR) \\
\hline 1. & Revenue (price per heads kampong chicken) & 5,000 \\
2. & Feed price per heads & 30,000 \\
3. & Other variable cost per heads & 9,000 \\
4. & Income perheads kampong chicken & 16,000 \\
\hline
\end{tabular}

Table 4. Break even point (BEP) kampong chicken raised

\begin{tabular}{clc}
\hline No. & \multicolumn{1}{c}{ Items } & Number (IDR) \\
\hline 1. & Price per heads kampong chicken) & 55,000 \\
2. & Fixed cost & 732,000 \\
3. & Variable cost per head & 43,000 \\
4. & BEP* kampong chicken (heads) & 61 \\
\hline
\end{tabular}

\section{CONCLUSIONS}

The production and marketing subsystem of agribusiness in kampong chicken in Batang regency was in a moderate category. Improving the production system through improving the bookkeeping record, the number of scale rearing and sanitation process would lead to good kampong chicken productivity. Increasing the marketing subsystem through the application of electronic marketing would improve market efficiency and cost. Application of agribusiness approach could improve the production and marketing system of kampong chicken business in Batang Regency.

\section{ACKNOWLEDGEMENT}

We would like to thanks reviewer and editor for the valuable input, also to Research and Extension Service Department of Universitas Diponegoro that give as funding support.

\section{REFERENCES}

Abdelqader, A., Wollny, C. B. A., \& Gauly, M. (2007). Characterization of local chicken production systems and their potential under different levels of management practice in Jordan. Tropical Animal Health and Production, 39, 155-165. https://doi.org/ 10.1007/s11250-007-9000-x

Anas, S., Rohmadi, D., \& Fadwiwati, Y. (2020). Potensi usaha dan analisis nilai tambah pemasaran ayam kampung di Gorontalo. Agrovital: Jurnal Ilmu Pertanian, 5(1), 47-50. Retrieved from https://journal.lppm-unasman. ac.id/index.php/agrovital/article/download/64 $1 / 521$

BPS-Statistics Indonesia. (2019). Statistical yearbook of Indonesia 2019. Jakarta: BPSStatistics Indonesia. Retrieved from https:// www.bps.go.id/publication/2019/07/04/daac 1 ba18cae1e90706ee58a/statistik-indonesia-201 9.html\#: :text=Statistik\%20Indonesia\%2020 19\%20merupakan\%20seri,demografi\%20dan $\% 20$ perekonomian\%20di\%20Indonesia

Desta, T. T., \& Wakeyo, O. (2012). Uses and flock management practices of scavenging chickens in Wolaita Zone of Southern Ethiopia. Tropical Animal Health and Production, 44, 537-544. https://doi.org/ 10.1007/s11250-011-9933-y

Desta, T. T., \& Wakeyo, O. (2013). Village chickens management in Wolaita Zone of Southern Ethiopia. Tropical Animal Health and Production, 45, 387-396. https://doi.org/ $10.1007 / \mathrm{s} 11250-012-0228-8$

Gondwe, T. N., \& Wollny, C. B. A. (2007). Local 
chicken production system in Malawi: Household flock structure, dynamics, management and health. Tropical Animal Health and Production, 39(2), 103-113. https://doi.org/10.1007/s11250-006-4293-8

Halima, H., Neser, F. W. C., van Marle-Koster, E., \& De Kock, A. (2007). Village-based indigenous chicken production system in North-West Ethiopia. Tropical Animal Health and Production, 39, 189-197. https://doi.org/ 10.1007/s11250-007-9004-6

Hasriani, Arifin, \& Pata, A. A. (2019). Faktorfaktor yang mempengaruhi permintaan ayam kampung di Kabupaten Maros. Jurnal Agribis, 1(1), 53-64. Retrieved from http:// ejournals.umma.ac.id/index.php/agribis/articl e/view/321

Haunshi, S., Doley, S., \& Shakuntala, I. (2009). Production performance of indigenous chicken of Northeastern Region and improved varieties developed for backyard farming. Indian Journal of Animal Sciences, 79(9), 901-905. Retrieved from https://www.cabdirect.org/ cabdirect/abstract/20093273052

Henning, J., Khin, A., Hla, T., \& Meers, J. (2006). Husbandry and trade of indigenous chickens in Myanmar-Results of a participatory rural appraisal in the Yangon and the Mandalay Divisions. Tropical Animal Health and Production, 38, 611-618. https://doi.org/ 10.1007/s11250-006-4425-1

Homer, B. E., Iyai, D. A., \& Sangkek, M. (2017). Sistem, konstrain, sustainabilitas, dan skenario peternakan ayam kampung di Manokwari, Papua Barat. Jurnal Sain Peternakan Indonesia, 12(1), 24-37. https://doi.org/ 10.31186/jspi.id.12.1.24-37

Ja'far, Baba, S., \& Abdullah, A. (2019). Pengaruh lama beternak terhadap tingkat adopsi teknologi perkandangan pada pemeliharaan ternak kambing di Kecamatan Limboro Kabupaten Polewali Mandar, 15(1), 46-50. Retrieved from http://ejournal.polbangtangowa.ac.id/index.php/J-Agr-Sosekpenyuluhan /article/view/7

Loing, J. C., \& Makalew, A. (2016). Analisis finansial usaha ternak ayam kampung di Kecamatan Kawangkoan kawasan agropolitan Kabupaten Minahasa. Jurnal
LPPM Bidang Sains Dan Teknologi, 3(1), 5156. Retrieved from https://ejournal.unsrat.ac. id/index.php/lppmsains/article/view/15207

Mahoro, J., Muasya, T. K., Mbuza, F., Habimana, R., \& Kahi, A. K. (2017). Characterization of indigenous chicken production systems in Rwanda. Poultry Science, 96(12), 4245-4252. https://doi.org/10.3382/ps/pex240

Mastuti, S., \& Hidayat, N. N. (2009). Peranan tenaga kerja perempuan dalam usaha ternak sapi perah di Kabupaten Banyumas. Animal Production, 11(1), 40-47. Retrieved from http://www.animalproduction.net/index.php/J AP/article/view/221

Moussa, H. O., Keambou, T. C., Hima, K., Issa, S., Motsa, S. J., \& Bakasso, Y. (2019). Indigenous chicken production in Niger. Veterinary and Animal Science, 7, 100040. https://doi.org/10.1016/j.vas.2018.11.001

Mtileni, B. J., Muchadeyi, F. C., Maiwashe, A., Chimonyo, M., Mapiye, C., \& Dzama, K. (2013). Influence of socioeconomic factors on production constraints faced by indigenous chicken producers in South Africa. Tropical Animal Health and Production, 45, 67-74. https://doi.org/10.1007/s11250-012-0175-4

Muchadeyi, F. C., Wollny, C. B. A., Eding, H., Weigend, S., Makuza, S. M., \& Simianer, H. (2007). Variation in village chicken production systems among agro-ecological zones of Zimbabwe. Tropical Animal Health and Production, 39, 453-461. https://doi.org/ 10.1007/s11250-007-9050-0

Okeno, T. O., Kahi, A. K., \& Peters, K. J. (2012). Characterization of indigenous chicken production systems in Kenya. Tropical Animal Health and Production, 44(3), 601608. https://doi.org/10.1007/s11250-011-994 $2-\mathrm{x}$

Oskar, B., Darus, H. M. M. B., \& Iskandarini. (2013). Analisis faktor-faktor yang mempengaruhi perilaku konsumen dalam mengkonsumsi daging ayam kampung di Kota Medan (Studi kasus: Pasar Sambas, Medan). Journal on Social Economic of Agriculture and Agribusiness, 2(10), 1-11. Retrieved from https://media.neliti.com/media/publications/1 5144-ID-analisis-faktor-faktor-yang-mempe ngaruhi-perilaku-konsumen-dalam-mengkon 
sumsi-da.pdf

Paltasingh, K. R., \& Goyari, P. (2018). Impact of farmer education on farm productivity under varying technologies: Case of paddy growers in India. Agricultural and Food Economics, 6(7), 1-19. https://doi.org/10.1186/s40100018-0101-9

Penggu, P., Santa, N. M., Makalew, A., \& Waleleng, P. O. V. (2014). Hubungan biaya produksi dengan pendapatan usaha ternak ayam kampung (Studi kasus di Desa Pungkol, Kecamatan Tatapaan, Kabupaten Minahasa Selatan). Zootek, 34, 67-75. https:// doi.org/10.35792/zot.34.0.2014.4794

Rahayu, R. S., Roessali, W., Setiadi, A., \& Mukson. (2014). Kontribusi usaha sapi perah terhadap pendapatan keluarga peternak di Kecamatan Getasan Kabupaten Semarang. Agriekonomika, 3(1), 45-54. Retrieved from https://journal.trunojoyo.ac.id/agriekonomika/ article/view/439

Rahmah, U. I. L. (2015). Analisis pendapatan usaha ternak ayam ras pedaging pada pola usaha yang berbeda di Kecamatan Cingambul Kabupaten Majalengka. Agrivet: Jurnal Ilmu Pertanian dan Peternakan, 3(1), 1-15. Retrieved from https://www.jurnal.unma.ac.id /index.php/AG/article/view/194/0

Rasyaf, M. (2010). Manajemen peternakan ayam kampung. Yogyakarta: Kanisius.

Rodríguez, L. C., Herrero, M., \& Baltenweck, I. (2011). Community-based interventions for the use and conservation of animal genetic resources: The case of indigenous scavenger chicken production in Benin. Tropical Animal Health and Production, 43, 961-966. https:// doi.org/10.1007/s11250-011-9790-8

Rosningsih, S. (2012). Kajian sosial ekonomi pengembangan ayam kampung di Argorejo Sedayu Bantul. Jurnal AgriSains, 3(4), 20-32. Retrieved from https://ejurnal.mercubuanayogya.ac.id/index.php/Agrisains/article/view/ 39

Sekeroglu, A., \& Aksimsek, S. D. (2009). Village chicken production in Turkey: Tokat Province example. Tropical Animal Health and Production, 41, 103-108. https://doi.org/ 10.1007/s11250-008-9163-0
Setiadi, A., Santoso, S. I., Sumarsono, Mahfudz, L. D., \& Susanto, A. B. (2016). An economic analysis of kampung chicken production using the small water plant Azolla microphylla in their feed. Pakistan Journal of Nutrition, 15(3), 264-267. https://doi.org/10.3923/pjn. 2016.264.267

Setiana, L., Sugiarto, M., \& Djatmiko, O. E. (2019). Socio demographic factors influencing the income of native chicken farming in rural area of Ciamis Regency. Animal Production, 21(2), 110-115. https://doi.org/10.20884/1.jap .2019.21.2.757

Sinaga, A., Salmiah, \& Kesuma, S. I. (2014). Faktor-faktor yang mempengaruhi permintaan daging ayam kampung. Journal on Social Economic of Agriculture and Agribusiness, 3(2), 1-10. Retrieved from https://media. neliti.com/media/publications/15194-ID-fakto r-faktor-yang-mempengaruhi-permintaan-dagi ng-ayam-kampung.pdf

Soekartawi. (2006). Analisis usaha tani. Jakarta: UI Press.

Sofyan, A., Suprijatna, E., Santosa, S. I., \& Setiadi, A. (2019). Business sustainability model of smallholder layer farms in Kendal Regency, Central Java, Indonesia. Journal of the Indonesian Tropical Animal Agriculture, 44(4), 408-414. https://doi.org/10.14710/jitaa. 44.4.408-414

Sow, T. M. A., \& Grongnet, J. F. (2010). Sensory characteristics and consumer preference for chicken meat in Guinea. Poultry Science, 89(10), 2281-2292. https://doi.org/10.3382/ ps.2010-00679

Suharyon, Zubir, \& Susilawati, E. (2020). Analisis ekonomi dan kelembagaan usaha ternak ayam kampung (Kub) di Kecamatan Jambi Selatan Kabupaten Muaro Jambi. Jurnal Ilmiah Ilmu Terapan Universitas Jambi, 4(1), 24-33. Retrieved from https://online-journal. unja.ac.id/JIITUJ/article/view/9785

Teklewold, H., Dadi, L., Yami, A., \& Dana, N. (2006). Determinants of adoption of poultry technology: A double-hurdle approach. Livestock Research for Rural Development, 18(3), 75-86. Retrieved from https://www. lrrd.org/lrrd18/3/tekl18040.htm 
Wantasen, E., Elly, F. H., \& Santa, N. M. (2014). The analysis of semi intensive native chicken farming in rural communities (Case study on farmers group "Poyuyanan" in Poyowa Besar Village, South Kotamobagu District, North Sulawesi Province). Journal of the Indonesian Tropical and Animal Agriculture, 39(2), 126133. https://doi.org/10.14710/jitaa.39.2.126133

Widjastuti, T., Asmara, I. Y., \& Anang, A. (2018). Pengembangan ayam lokal di Indonesia. In
Prosiding Seminar Nasional Pengembangan Unggas Lokal di Indonesia (pp. 15-22). Universitas Sam Ratulangi. Retrieved from http://repo.unsrat.ac.id/1939/4/article_002.pdf

Widyantari, I. N. (2015). Analisis kelayakan finansial usaha ayam kampung di Distrik Semangga Kabupaten Merauke. Agricola, 5(1), 47-54. Retrieved from http://www. ejournal.unmus.ac.id/index.php/agricola/articl e/view/410/ 